\title{
Assessment Of Money Illusion Impact On Individuals' Economic Behaviour In Lithuania
}

\author{
Daiva Jureviciene, Prof., PhD \\ Mykolas Romeris University, \\ Vilnius Gediminas Technical University, Lithuania \\ Jekaterina Markelova, MA \\ Mykolas Romeris University, Lithuania
}

doi: 10.19044/esj.2016.v12n13p1 URL:http://dx.doi.org/10.19044/esj.2016.v12n13p1

\begin{abstract}
Behavioural economics was in a process of rapid development in the last century. One of behavioural phenomenon discovered by economists is money illusion - an inclination to make biased decisions based on nominal rather than real monetary values. This illusion influences individuals' perception of money-related processes and, hence, their economic behaviour. Euro illusion concept, which represents money illusion in countries that adopted the euro, became commonly used after money illusion has been identified and studied in a number of Euro zone countries. Money illusion has not been deeply discussed in Lithuania. The euro introduction in 2015 provides an additional reason to study its impact on Lithuanian citizens. The purpose of the paper is to evaluate money illusion impact on individuals' economic behaviour in Lithuania after assessment whether Lithuanians experience it. Analysis of scientific literature, experimental study and statistical methods were applied. It was found that citizens are prone to money illusion, which causes irrational economic behaviour. Despite difficult adaptation to the euro, Lithuanians do not experience euro illusion. Newly collected data on money illusion in Lithuania suggests critical evaluation of individuals' economic behaviour. Performance of such experiment has some limitations as problems presented in a survey are hypothetical and decisions made by participant may not extend to real world. In addition participants may bear in mind their own assumptions like personal experience (e.g. income, savings, debts etc.) which could affect their decisions.
\end{abstract}

Keywords: Economic behaviour, money illusion, euro illusion, assessment of economic transactions, nominal and real values 


\section{Introduction}

Fisher introduced the concept of money illusion in economics in 1928. He discovered an inclination to make biased decisions by thinking in terms of nominal rather than real monetary values. Fisher argued that almost every individual influenced by money illusion in respect to his country's currency (Fisher 2012). Nominal value of money is a value expressed on the currency note. Real value differs from nominal one - it changes over time due to inflation. Therefore, we can state that inflation is one of the main reasons why money illusion effect appears. People used to deal with nominal values when making economic decisions evaluating and comparing prices, salaries, buying and selling products, using services etc., because it is much more convenient and simpler in everyday situations. Converting nominal to real terms requires efforts, which is most of the time considered dispensable (Desmet, 2002). The impact of money illusion in the short run may not be significant, while its impact in the end is more noticeable.

Confusing nominal with real values is a reason why people often perceive rises in salaries or prices as real gains. It means that money illusion distorts individuals' perception of the growth of wealth and thus affects spending and savings decisions (Miao, Xie, 2013). In fact, abovementioned should be interpreted because of a general process of wage and price inflation rise (Burgoyne et al., 1999). It can be assumed that if individuals were not confused by inflation they would not experience money illusion and their economic behaviour would be more rational (Fisher, 2012; Fisher, Modigliani, 1978). However, Shafir et al. (1997) state that money illusion may extend to noninflationary circumstances, such as using unfamiliar currency. People are prone to money illusion when they have to deal with a currency to which they are not used to in their daily life. An example of such situation in a country is a change from one currency to another.

Difference between new nominal value and real value of money create distortion in people's behaviour (Missier et al., 2007) - they lose their sense of value for a currency, frame of reference. Even though currency changeover does not change the real value of money and to convert an old currency to a new one requires simple multiplication or dividing operation, people often use old currency as a general benchmark, and thus, suffer from money illusion. That is why all decisions need to be considered more carefully in this period and the main task for citizens is to learn the value of a new currency (Garling, Thogersen, 2007).

The aim of this article is to assess whether Lithuanians experience money illusion and, after the identification of its existence, to evaluate the impact of money illusion on individuals' economic behavior in Lithuania. 
Methods of the research include systematic and comparative analysis of scientific literature, experimental study, and statistical methods. Results of the research can be helpful in understanding individuals' economic decisions, their perception of money-related processes and phenomenon. The research presents a newly collected data on money illusion impact in Lithuania, as well as promotes critical evaluation of citizens' economic behavior, considering the effect of money illusion.

\section{The impact of money illusion on individuals' economic behaviour}

The main channel through which the impact of money illusion on economic behaviour is most noticeable is individuals' perception of transactions' value. For example, money illusion changes evaluation of prices, which results in making irrational economic decisions. Price perception is individual's assessment of value obtained from a particular price (Desmet, 2002). In other words, it is decoding from a price scale to a value scale. When there is no change in value of the money, the process of price evaluation becomes rather automatic. When the value changes due to inflation or currency changeover, the link of price and its value is cut (Desmet, 2002). It creates a possibility for money illusion to appear.

People have a choice in such cases - to adapt and learn new price scale or to convert new prices to old ones. Adaptation strategy is more intuitive and assessment of new prices is typically based on prices of products, which a consumer is used to buy frequently. This tendency refers to adjustment and anchoring heuristic (Gaston-Breton, 2006). The conversion strategy usually arises during currency changeover. It can be used as exact calculation or approximate conversion to familiar currency (Missier et al., 2007). In case of exact conversion, there is less possibility for money illusion to appear. In all other cases there is a chance that consumer evaluates new prices inaccurately and experiences by money illusion.

The move from familiar pricing scale to lower or higher one changes the interpretation of prices and their differences. It was found that currency with lower nominal value makes prices appear smaller than prices expressed in currency with higher nominal value (Raghubir, Srivastava, 2002; van Raaij, van Rijen, 2003; Dzokoto et al., 2010). It means that individuals spend their budgets more easily while using currency with lower nominal value. Differences between prices also appear slighter - it is called compression effect (Gamble, 2007). These tendencies can be explained by numerosity heuristics. Wertenbroch et al. (2007) proved that subjective evaluation of economic transaction is motivated by the numerosity of the nominal difference between the price of transaction and reference standard (budget or reference price). Such 
logic is irrational, as the concept of numerosity is not the same as quantity. Numerosity is the number of units into which something is divided, but not the quantity, thus numerosity heuristic is a false opinion that "many" means "much" (Ramonienè, Brazys, 2007).

Individuals perceive the price as higher if it can be divided into more small units. For example, the price of 10 EUR appears cheaper than the price of $34.53 \mathrm{LTL}^{1}$, although the value of both prices is the same (1 EUR $=3.4528$ LTL). Therefore, the number of units into which the price can be divided plays a greater role in decision-making process that the real value (size) of each unit. That is why prices expressed in a currency with lower nominal value appear cheaper.

The effect of numerosity heuristic also appears when consumers compare prices of two products in different currencies. For example, one product costs 10 EUR (34.53 LTL), another one - 12 EUR (41.43 LTL). The difference between prices of two EUR (12 - 10) is perceived as rather small in comparison with the difference of 6.9 LTL (41.43 - 34.53), since the latter is more numerous. Thus, a consumer will be more willing to pay for more expensive product if its price is expressed in currency with lower nominal value.

On the other hand, there is another side of numerosity heuristic, when individuals assess transaction in the context of budgetary constraints. According to the theory called Difference Assessment Account (DAA), individuals perceive the value of an economic transaction by comparing the numeral of the difference between the price and given budget (Wertenbroch et al., 2007). For example, a consumer is given a budget of 40 EUR (138.11 LTL). The price of a product is 10 EUR (34.53 LTL). According to the DAA, a person will be more willing to pay $34.53 \mathrm{LTL}$ than 10 EUR, because the nominal difference between the price and the budget expressed in LTL $(138.11-34.53=103.58)$ is more numerous than expressed in EUR $(40-10=30)$. Thus, the more numerous is the difference between the price and given budget, the more an individual is ready to spend his money.

The relationship between price perception and exchange rate between two currencies can be observed. Desmet (2002) hypothesized that the higher the exchange rate is, the cheaper the prices appear due to numerous heuristic, and thus people are more prone to suffer from money illusion. However, this tendency is not a rule. It was found that in some situations; if the exchange rate is low, (when prices in two different currencies look similar); people tend to use familiar currency as a

${ }^{1}$ LTL - abbreviation of Lithuanian currency litas before joining Eurozone in the beginning of 2015 with fixed value 1 Euro equals 3.4528 litas. 
reference when assessing prices in unfamiliar currency, thus increasing the probability of making a mistake. When the exchange rate is high (when the nominal values of prices differ substantially), price scales become incompatible and people convert new currency to the old one using converter, thus minimizing the risk of a mistake (Desmet, 2002; Kerem et al., 2013).

\section{Money illusion in the context of the euro introduction}

The concept of euro illusion was presented during the introduction of European Monetary Union's common currency the euro. It is related to money illusion and is, basically, the same phenomenon. It emphasizes the influence of nominal monetary values on perception of economic transactions after a country adopts the euro.

Eventually, the common currency should benefit citizens due to convenience since there is no need to exchange currency travelling to another Euro zone country. It also brings the opportunity to compare prices in different countries more precisely. It should make the market more competitive and lead to lowering the prices of goods and services across the Euro zone (Gamble 2007). However, adaptation to the euro is not an easy process - citizens need to adapt too many changes as prices, salaries and all financial contracts are converted to euro. They are forced to learn new value scale. Difficult adaptation gives a possibility for euro illusion to appear.

Antilla (2004) states that consumers' price-consciousness decreases during transition to the euro. They are confused about changes in prices and find it difficult and time-costly to assess them. Prices expressed in euro create euro illusion - citizens evaluate new prices differently from prices before the introduction of the euro. This happens due to differences in nominal values of currencies. The euro has lower nominal value than most of old currencies in Euro area with an exception of Ireland and Latvia. Thus, prices appear lower in those countries - they were divided by 1.95 in Germany, 2.20 in The Netherlands, 6.55 in France, 40.34 in Belgium, 166 in Spain, 200 in Portugal and even 1936 in Italy (Gaston-Breton, 2006). This kind of change in the price scale leads to euro illusion and change in individual's economic habits as people tend to evaluate nominal rather than real values.

Researchers in several Euro zone countries studied an effect of euro illusion. Anttila (2004) examined how Finnish consumers perceive prices after the introduction of the euro, and euro illusion was found to exist in Finland to some extent. Missier et al. (2007) compared the effect of euro illusion in Italy and Ireland because they have greatest difference in exchange rate from national currency to the euro (1 EUR $=0.79$ IEP, 1 
EUR = 1936 ITL). Euro illusion was found to be stronger in Italy due to extreme exchange rate. Thus, Italian consumers had more difficulties in assessment of prices - they often used lira as a reference. The effect of euro illusion in Ireland was weaker because the nominal values of Irish pound and euro were close to each other. Van Raaij and van Rijen (2003) showed that citizens of The Netherlands also experienced the effect of euro illusion after the currency changeover. Consumers perceived new prices cheaper than old prices expressed in Dutch guilders due to lower nominal value of the euro. A tendency to convert one currency to another one inaccurately and to use old reference points was also found.

The currency changeover affects not only assessment of prices, but income as well. In most Euro zone countries, citizens perceived their salaries as smaller when they were converted from domestic currency to the euro. In this way, euro illusion causes people to feel poorer (Gamble 2007).

It can be assumed that the steepness of euro illusion effect depends on exchange rate between the euro and national currency of the country. Most often, the higher the exchange rate, the bigger is illusion effect in the country. However, Desmet (2002) found that it is not valid for all countries. For example, in Spain with higher exchange rate (1:166) observed effect of euro illusion was smaller than in Germany with lower conversion rate (1:1.956). Therefore, there was proposed alternative explanation - the size of euro illusion depends more on difficulty of mental conversion from one currency to another. Desmet (2002) has noted a paradoxical fact that often the more difficult mental computation the exchange rate requires, the more often citizens use a converter and assess prices accurately, the smaller is the effect of euro illusion in the country. Accordingly, when the exchange rate is simple, consumers perform mental computation and round exchange rate, or use old reference points. This can leads to mistakes in assessment of prices and creates euro illusion effect (Kerem et al., 2013).

On one hand, mental conversion of euro to the national currency makes people rely on old price scale longer. They assess prices based on old reference points and do not create new ones. Thus, consumers who use this strategy are prone to anchoring bias and intuitive price estimation, which can lead to euro illusion (Missier et al., 2007). On the other hand, when consumers convert prices by using converter - it also slows down the process of relearning prices; however, it weakens the effect of euro illusion.

The adaptation to the euro may last long. In Ireland and Italy euro illusion was found to exist on the third year after the introduction of the euro (Missier et al., 2007). In some cases, the adaptation may take less 
time. For example, in Austria the relearning to the euro scale was processing quite smoothly and quickly in comparison with Portugal, where the adaptation tooks longer (Gamble, 2007). Germans have also adapted the euro easier comparing to citizens of most other Euro zone countries (Jonas, 2003).

In order to make the transition to the euro easier for citizens, the dual cash circulation is introduced in the country when payments can be done in both euro and national currency. The system of dual pricing is also used when retailers are obliged to provide prices expressed in both euro and national currency. It was assumed that this strategy would facilitate the relearning of new prices (Gamble, 2007). However, in practice this system is often criticized as it forces people to rely on old reference points longer - citizens continue to make economic decisions based on the old national currency. This tendency was noticed in Estonia, Austria and other Euro zone countries (Glauben et al., 2004). Thus, dual pricing does not motivate consumers to adapt to the euro.

One of the factors, which can prevent citizens from smooth adaptation to the euro, is their negative attitude towards the new currency. After the cross-country research conducted in Ireland and Italy, Missier et al. (2007) concluded that relearning of new currency scale causes annoyance between citizens. People experience personal negative outcomes and, therefore, in the long term usually have negative attitude towards the euro. Estonians also expressed pessimistic feelings about the euro (Kerem et al., 2013). Van Raaij and van Rijen (2003) found that most of The Netherlands citizens had negative opinion about the euro. Consequently, consumers may evaluate the euro as less valuable currency and assess new prices inaccurately.

All mentioned factors complicate the evaluation of prices and the adaptation to the euro, therefore create an opportunity for euro illusion to be stronger in a country.

\section{The research of money illusion impact on individuals' economic behaviour in Lithuania:}

Experimental study was conducted to examine money illusion and its impact on individuals' economic behaviour in Lithuania. Its model is based on researches of Shafir et al. (1997), Missier et al. (2007), Wertenbroch et al. (2007). Random sampling method was used for selecting participants of the experiment. These criteria were set in order to ensure that an individual has experience in using both currencies (litas and euro) and is used to make economic decisions independently. Thus, the target population in this research are Lithuanians older than 18 years. 
Selection method of a sample ensures that the results will be valid for target population.

The experimental study was designed in form of structured questionnaire with closed- and open-ended questions, which were presented to participants of the experiment. Independent variables in this case were budget and prices expressed in two different currencies (litas and euro with different numerosity) which were manipulated. The dependent variable was consumers' assessment of economic transaction.

The questionnaire used in the experiment is comprised of introduction and 21 questions divided into four sections (Demographic questions; Adaptation to the euro and attitude related questions; Money illusion related questions; Euro illusion related questions). The experiment was conducted with two groups of participants in two places - with employees of bank office based in capital city and with employees of a firm based in one town. Two groups of participants did not differ in some important way and the purpose of the experiment is not to compare two groups, but to compare the results of two sessions. Thus, the results are presented and analysed in a combined format as of one big group of participants.

Twenty-five Lithuanians above 18 years were chosen to participate in the experiment, which was performed in two sessions with the same group of people. Participants were given sheets of paper with questions and problems posed in a questionnaire format. In the first session questions 1-6, 13-15, 18, 20 were asked. In the second - 7-12, 16-17, 19, 21. The purpose of making two session and dividing questions into two parts was to ensure unbiased decisions made by participants regarding questions where formulation is the same but the currency and numerosity differ (however real values are the same). If participant received these questions in one session they would have compared them and made biased decisions. Questions were written in English, however translation to Lithuanian language was also prepared in case participants have difficulties with understanding questions.

Following statistical methods were used for the analysis of the data: descriptive statistics (tables, graphics), Pearson's chi-square test, paired samples t-test, Spearman's correlation coefficient, Wilcoxon signed-rank test.

It was investigated whether individuals' experienced money illusion effect is related to their attitudes towards the euro and whether adaptation to the euro is topical issue among Lithuanian citizens. The following most important points can be distinguished:

$28 \%$ of experiment participants have negative attitude towards the introduction of the euro and the same percentage evaluates their adaptation to the euro as difficult. The results of Spearman's correlation analysis indicate that there 
is significant strong positive correlation between these factors $(\rho=0.651$; $\mathrm{p}=0.000425$ ) - the better the attitude of an individual is, the easier for him/her is adaptation process, and vice versa. This phenomenon can be explained by pure psychology - an individual is reluctant to get familiar and adapt to events that he/she evaluates negatively.

More than a half of participants (56\%) experience a lot or some difficulties using euro until today (nearly a year of euro circulation in Lithuania). There was found a strong association between the difficulty of the adaptation process and the trouble which the euro causes for an individual today $(\rho=0.792$; $\mathrm{p}=0.000002$ ) - those who had easier adaptation period have fewer difficulties today. However, those who evaluate their adaptation as difficult are still experiencing problems using euro. It can be stated that after 9 months since the euro was introduced in January 2015, individuals are still adapting to the new currency.

The majority of citizens still count mentally in litas - 48\% of the respondents evaluate daily purchases in litas, $56 \%$ assess exceptional (expensive) purchases in litas.

Previous experience of using the euro in other Euro zone countries or individuals' education level has no impact on their attitude towards the euro, as well as on adaptation process and do not make it easier. Spearman's correlation test showed no significant correlation between individuals' trips to Euro zone countries made in past 10 years and their attitude towards the euro $(\rho=0.373$, $\mathrm{p}=0.066)$ and difficulty of adaptation $(\rho=0.250, \mathrm{p}=0.228)$. There is also no significant correlation between individuals' education level and their attitude towards the euro $(\rho=0.053, \mathrm{p}=0.802)$ and difficulty of adaptation process $(\rho=0.142, \mathrm{p}=0.5)$.

\section{Money illusion in Lithuania}

It was investigated how participants evaluate economic transactions and their income - in real or nominal monetary terms in order to determine if individuals are prone to money illusion.

Individuals' assessment of income was investigated in the first study of money illusion. Participants were given a problem and were asked to evaluate who, of two persons, did better in economic terms and who was happier after the raise in salary under different inflationary conditions. When economic terms were emphasised, $80 \%$ of respondents associated wellbeing to real gains in income (adjusted with inflation level). However, when asked about feeling of happiness and economic terms were not stressed, $72 \%$ of participants related wellbeing to nominal gains without considering the effect of inflation (Fig. 1). 


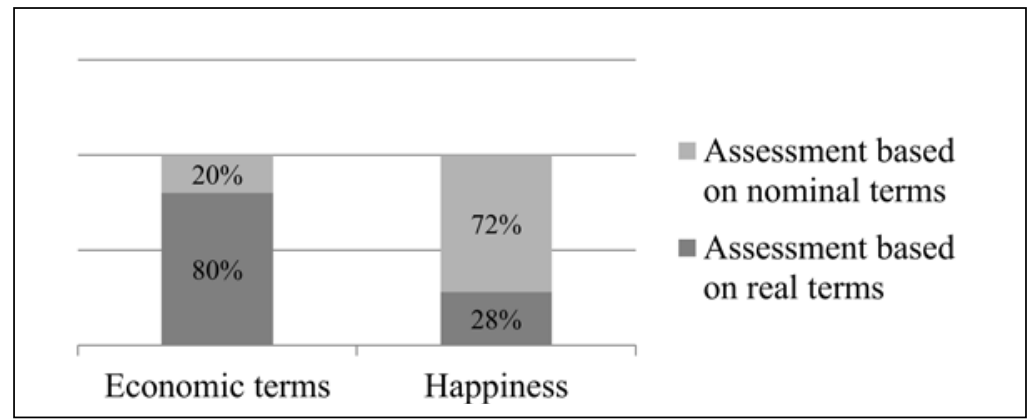

Fig. 1. Individuals' assessment of raise in salary in economic terms and in terms of happiness (Source: authors' compilation)

Chi-square tests for both questions confirmed that the difference between groups of people who chose different answers is significant $\left(\chi^{2}=4.84, \mathrm{p}=0.028 ; \chi^{2}=9.0, \mathrm{p}=0.003\right)$, therefore such results could not appear incidentally.

Wilcoxon signed-rank test applied to evaluate the difference between two sets of answers (when economic terms are emphasized, and when happiness is stressed). It was used to compare comparing two sets of scores, which come from the same participants, and is a non-parametric equivalent of the dependent $t$-test (Field, 2005). The test shows that there is a significant difference between answers $(Z=-3.153 ; p=0.002)-15$ individuals distinguish real gains when economic terms are emphasized, but attribute feeling of happiness to nominal terms.

Overall, it can be stated that the problem is not that people cannot distinguish between real and nominal terms, but that they see the difference only when they are forced to think in economic terms, but not in usual conditions. When individuals are not asked to think about economic benefit, they focus on nominal terms and attribute happiness to nominal raises, despite lower raises or even decreases in real terms. These findings correspond to conclusions made by Shafir (1997) in his initial study of money illusion.

To investigate whether money illusion effect is related to individuals' demographic characteristics, Spearman's correlation test was applied. It revealed that there is no significant association between individuals' ability to distinguish between nominal and real terms and such factors as gender, age, income, and education level (Table 1). 
Table 1. Spearman's correlation - individuals' ability to distinguish between nominal and real terms in the first study of money illusion / demographic factors (Source: author's compilation)

\begin{tabular}{|c|c|c|c|c|c|}
\hline \multicolumn{2}{|c|}{} & Gender & Age & $\begin{array}{c}\text { Monthly income in } \\
\text { EUR }\end{array}$ & Education level \\
\hline $\begin{array}{c}\text { Ability to distinguish } \\
\text { between nominal and } \\
\text { real terms (in the first } \\
\text { study) }\end{array}$ & $\rho$ & .040 & .100 & .063 & -.124 \\
\cline { 2 - 7 } & $\mathrm{p}$ & .848 & .633 & .765 & .554 \\
\cline { 2 - 7 } & 25 & 25 & 25 & 25 \\
\hline
\end{tabular}

Individuals had to indicate at which point of time they would like to buy or sell a product (computer) under stated conditions of inflation now, before the inflation or there is no difference in the second study. The right answer is "no difference" as the price of the product increased by $25 \%$ (from 400 EUR to 500 EUR) after the inflation of 25\%. Individuals' ability to distinguish between nominal and real monetary values while evaluating economic transactions was tested.

The results showed that $48 \%$ of individuals see no difference when to buy a computer and $32 \%$ see no difference when to sell it. It can be assumed that they understand that the real price has not changed. It is noteworthy that less than a half of participants chose the answer "no difference" in both questions. This observation corresponds with the results of similar questions used by Shafir (1997).

The third study suggested solving more complicated problem. Three deals of buying houses at the same price and selling them after some period under different inflationary and deflationary conditions were presented to participants. They had to assign ranks for all three deals (from " 1 " - the best, to " 3 " - the worst).

The table below illustrates ranks of the deals in term of real and nominal gains and the percentages of individuals' who chose each rank (Table 2).

Table 2. Comparison of the results of the second study of money illusion (Source: author's compilation)

\begin{tabular}{|c|c|c|c|}
\hline & $1^{\text {st }}$ deal & $2^{\text {nd }}$ deal & $3^{\text {rd }}$ deal \\
\hline Real Rank & 1 & 2 & 3 \\
\hline Nominal Rank & 3 & 2 & 1 \\
\hline Results: & $36 \%$ & $16 \%$ & $48 \%$ \\
1 & $24 \%$ & $60 \%$ & $16 \%$ \\
2 & $40 \%$ & $24 \%$ & $36 \%$ \\
\hline
\end{tabular}

It is clear that most of experiment participants were assessing economic transactions in nominal terms - the majority $(48 \%)$ of individuals' assigned first rank to the worst deal and third rank (40\%) to the best deal. 
It is worth to investigate what is the proportion of subjects who chose the right ranking model (first deal - "1", second deal - " 2 ", third deal - "3") since there could be several different combinations of ranking. The chart below shows that $72 \%$ of participants have assigned wrong ranks and $28 \%$ did it in the right way by assessing real gains and losses instead of focusing on nominal values (Fig. 2). Chi-square test proved that there is a significant difference between groups of subjects who chose the right and wrong ranking and it could not occur incidentally $\left(\chi^{2}=4.84\right.$, $\mathrm{p}=0.028$ ). Thus, it can be stated that the majority of subjects evaluate economic transactions by counting in nominal monetary values and do not consider inflation or deflation.

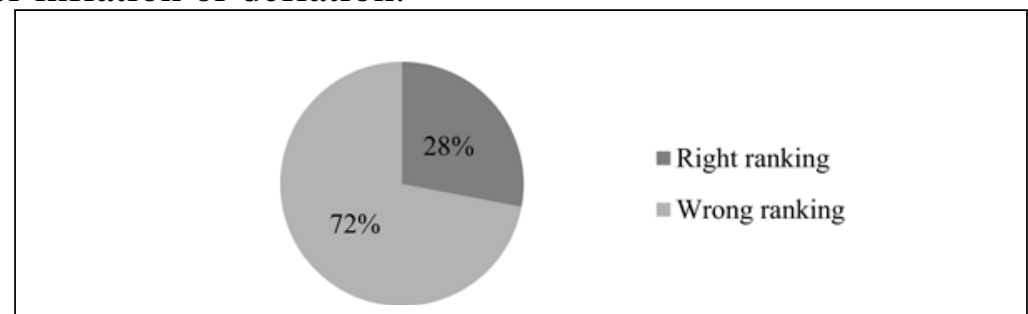

Fig. 2. Distribution of right and wrong rankings in the third study of money illusion (Source: authors' compilation)

Spearman's correlation analysis revealed that there is no significant association between individuals' ability to distinguish real and nominal values (chosen order of ranks) and such demographic factors as age, gender, and income and education level (Table 3).

Table 3. Spearman's correlation - individuals' ability to distinguish between nominal and real terms in the third study of money illusion / demographic factors (Source: authors' compilation)

\begin{tabular}{|c|c|c|c|c|c|}
\hline & & Gender & Age & $\begin{array}{c}\text { Monthly income in } \\
\text { EUR }\end{array}$ & $\begin{array}{c}\text { Education } \\
\text { level }\end{array}$ \\
\hline \multirow{3}{*}{$\begin{array}{l}\text { Ability to distinguish between } \\
\text { nominal and real terms (in the } \\
\text { second study) }\end{array}$} & $\rho$ & -.165 & -.013 & .342 & .306 \\
\hline & $\mathrm{p}$ & .430 & .952 & .094 & .137 \\
\hline & $\mathrm{N}$ & 25 & 25 & 25 & 25 \\
\hline
\end{tabular}

\section{Euro illusion in Lithuania}

In the first study of euro illusion, individuals' willingness to pay in euro and litas is compared. Participants were asked to budget money for three different categories (in the first session in litas, in the second in euro). Real value of budgets is the same. Amounts budgeted in litas were converted to euro in order to compare the results.

Proportions of budgeted amounts for different categories in litas and euro are shown in Fig. 3. 


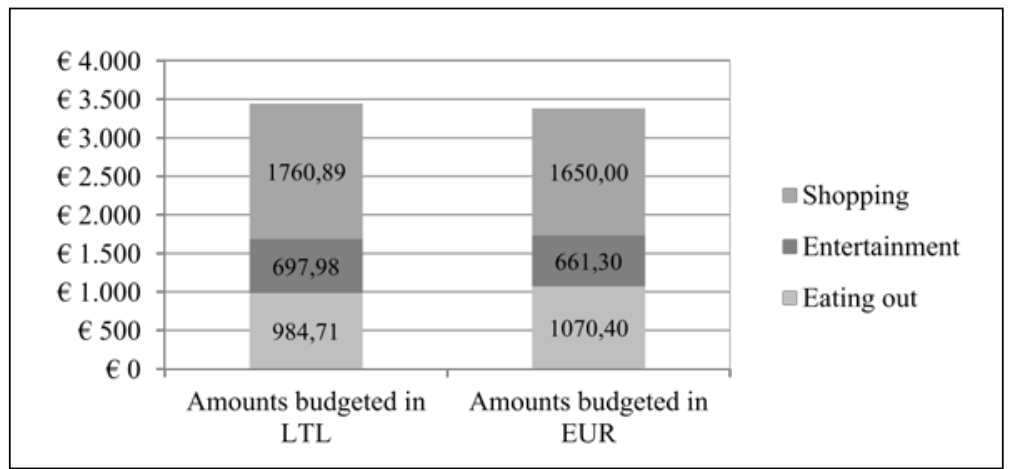

Fig. 3. Amounts budgeted in LTL and EUR (Source: authors’ compilation)

Total amounts are very similar - 3,443.58 EUR were budgeted in litas and 3,381.70 EUR in euro.

For investigating if the amounts that were budgeted in litas and euro are significantly different from each other, paired samples $t$-test was applied. It is used to assess the statistical significance of the difference between the means of two sets of data (Howitt 2005). The analysis revealed that there is no significant difference between two sets of budgeted amounts $(t=0.416, \mathrm{p}=0.681)$, thus it cannot be stated that individuals are more willing to pay in litas than in euro.

Results of the test allow concluding that individuals may assess economic transaction based on ratio between prices and given budget, and not on a difference between them. Another explanation could be that individuals convert prices expressed in euro to litas in order to evaluate them more accurately.

Spearman's correlation test did not show any significant association between individuals' budgeting decisions (the size of budgeted amounts in litas and euro) and such factors as individuals' age, gender, income, education level, travelling experience, as well as their attitude towards the introduction of the euro (Table 4).

Table 4. Spearman's correlation - budgeted amounts in litas and euro / demographic factors and attitude towards the euro (Source: authors' compilation)

\begin{tabular}{|c|c|c|c|c|c|c|c|}
\hline \multicolumn{2}{|l|}{} & & & $\begin{array}{c}\text { Monthly } \\
\text { income in } \\
\text { EUR }\end{array}$ & $\begin{array}{c}\text { Education } \\
\text { level }\end{array}$ & $\begin{array}{c}\text { Trips to Euro } \\
\text { zone countries } \\
\text { in past 10 } \\
\text { years }\end{array}$ & $\begin{array}{c}\text { Attitude } \\
\text { towards the } \\
\text { euro }\end{array}$ \\
\hline $\begin{array}{c}\text { Budgeted } \\
\text { amounts in LTL }\end{array}$ & $\rho$ & .073 & -.200 & -.163 & -.065 & .136 & -.115 \\
\cline { 2 - 8 } & $\mathrm{p}$ & .730 & .337 & .437 & .756 & .515 & .583 \\
\cline { 2 - 8 } & $\mathrm{N}$ & 25 & 25 & 25 & 25 & 25 & 25 \\
\hline $\begin{array}{c}\text { Budgeted } \\
\text { amounts in EUR }\end{array}$ & $\rho$ & .162 & -.267 & -.136 & .121 & .151 & .038 \\
\cline { 2 - 8 } & $\mathrm{p}$ & .438 & .196 & .517 & .564 & .472 & .855 \\
\cline { 2 - 8 } & $\mathrm{N}$ & 25 & 25 & 25 & 25 & 25 & 25 \\
\hline
\end{tabular}


The second study of euro illusion was intended to investigate if Lithuanians are more risk-averse making economic decisions using euro. Participant had to evaluate and make a choice between three investment options (A, B, C) expressed in litas and in euro. In first session, each investment option shows possible gain and loss expressed in litas, in second - in euro. Nominal values are different, however real values are the same. The options are decoded in following way: A - least risky, B medium risky, $\mathrm{C}$ - most risky decision.

The most common choice of subjects was B - investment option with medium risk. $40 \%$ of participants chose B in both sessions - when assessing alternatives in litas and euro. 20\% chose B in case of litas and less risky option of $\mathrm{A}$ in case of euro. $28 \%$ chose least risky alternative $\mathrm{A}$ in both sessions. The most risky option $\mathrm{C}$ was chosen by only three subjects - two of them chose $\mathrm{C}$ in case of litas, but B in case of euro; and only one participant chose $\mathrm{C}$ in both sessions.

It is noteworthy that none of individuals have chosen more risky option in case of euro than in case of litas $-72 \%$ of subjects have chosen investments with the same level of risk in litas as well as in euro, and $28 \%$ have chosen less risky investment in case of euro (Fig. 4).

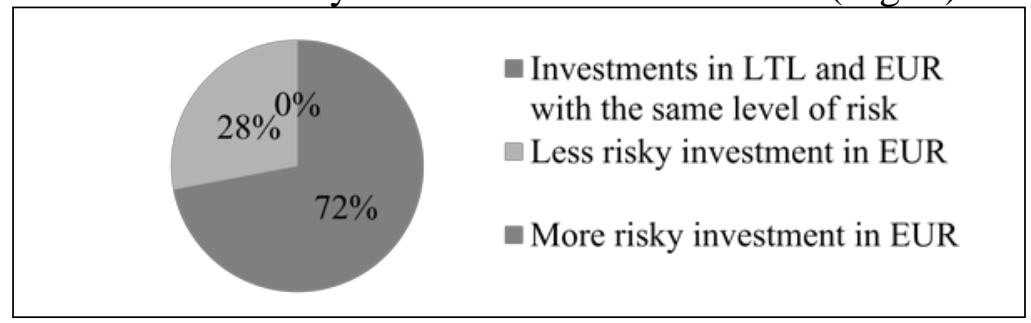

Fig. 4. Comparison of level of risk of investments chosen in LTL and EUR (Source: authors' compilation)

Spearman's correlation test revealed that there are no significant relations between individuals' investment decisions and such factor as their gender, age, income, level of education, as well as their attitude towards the introduction to the euro (Table 5).

Table 5. Spearman's correlation - investment decisions using litas and euro / demographic factors and attitude towards the euro (Source: authors' compilation)

\begin{tabular}{|c|c|c|c|c|c|c|c|}
\hline & & Gender & Age & $\begin{array}{l}\text { Monthly } \\
\text { income in } \\
\text { EUR }\end{array}$ & $\begin{array}{c}\text { Educatio } \\
\mathrm{n} \text { level }\end{array}$ & \begin{tabular}{|c|} 
Trips to Euro \\
zone countries \\
in past 10 years
\end{tabular} & $\begin{array}{c}\text { Attitude } \\
\text { towards the } \\
\text { euro }\end{array}$ \\
\hline \multirow{3}{*}{$\begin{array}{c}\text { Investment } \\
\text { decisions in LTL }\end{array}$} & $\rho$ & -.205 & .057 & -.199 & -.382 & .085 & .102 \\
\hline & $\mathrm{p}$ & .326 & .787 & .340 & .060 & .686 & .627 \\
\hline & $\mathrm{N}$ & 25 & 25 & 25 & 25 & 25 & 25 \\
\hline \multirow{3}{*}{$\begin{array}{l}\text { Investment } \\
\text { decisions in } \\
\text { EUR }\end{array}$} & $\rho$ & -.089 & -.125 & .093 & -.130 & -.133 & .371 \\
\hline & $\mathrm{p}$ & .674 & .553 & .658 & .536 & .527 & .067 \\
\hline & $\mathrm{N}$ & 25 & 25 & 25 & 25 & 25 & 25 \\
\hline
\end{tabular}


Overall, the results show that individuals are more risk-averse making investment decisions in euro. It can be explained by the fact that the euro is less familiar currency for them. The results correspond with the same observations made by Jonas (2003).

\section{Conclusion}

Money illusion is defined as behavioural phenomenon that refers to the tendency to make economic decisions based on nominal rather than real monetary values, i.e. when the face value of currency is mistaken for its real purchasing power. Individuals experience money illusion in two cases - when the effect of inflation on prices and income is overlooked, and when people use unfamiliar currency. In both cases, changes in nominal monetary terms make evaluation of prices complicated, and thus, cause money illusion.

During the adoption of the euro in European Monetary Union, the concept of money illusion has evolved to euro illusion. After the currency changeover in a country, citizens are influenced by anchoring and adjusting heuristic (confusing new prices with old reference points) and numerosity heuristic (confusing quantity of money with their real purchasing power).

The results showed that Lithuanian citizens are prone to the effect of money illusion. Despite the fact that most of them understand the essence of inflation and are able to distinguish between nominal and real monetary terms, Lithuanians rely on nominal value of money making economic decisions. Money illusion influences individuals' evaluation of transactions, prices and income level. Incorrect perception of real value of money leads to irrational economic behaviour. It appears while determining price acceptability and rejection zones, deciding what goods and services should be chosen, evaluating income and planning budget using nominal monetary terms.

The experiment revealed that Lithuanian citizens do not experience euro illusion. Although the introduction of the euro in Lithuania led to a change in nominal value of the currency, negative attitudes towards the euro and difficulties in assessing prices expressed in euro, Lithuanians' economic decisions and willingness to pay have not changed significantly. It can be explained by the fact that due to difficult psychological adaptation citizens still use litas as a reference point for making economic decisions. This habit slows down the adaptation process; however, it helps to assess economic transactions correctly and to avoid euro illusion.

The results showed that individuals' demographic characteristics (such as gender, age, income, education level) do not determine whether and 
to what extent they are prone to money illusion. There was also found no significant association between individuals' attitudes towards the introduction of the euro and their propensity to experience money illusion.

\section{References:}

Anttila, M. (2004). Consumer price perceptions after translation to Euro currency. Journal of Product \& Brand Management, 13(1), p. 47-55.

Burgoyne, C.B., Routh, D.A., \& Ellis, A-M. (1999). The Transition to the Euro: Some Perspectives from Economic Psychology. Journal of Consumer Policy, (22), p. 91-116.

Desmet, P. (2002). A study of the potential effects of the conversion to euro. Journal of Product \& Brand Management, 11(3), p.134-146.

Dzokoto, V., Mensah, C., Twum - Asante, M., \& Opare -Henaku, A. (2010). Deceiving Our Minds: A Qualitative Exploration of the Money Illusion in Post-redenomination Ghana. Journal of Consumer Policy, (33), p. 339-353.

Field, A. (2005). Discovering statistics using SPSS. $2^{\text {nd }}$ edition. - London; Thousand Oaks (Calif.); New Delhi: SAGE Publications.

Fischer, S., \& Modigliani, F. (1978). Towards an understanding of the real effects and costs of inflation. NBER Working Paper Series. - Cambridge (MA): National bureau of economic research, Working Paper 303. [Accessed 28.01.2016]. Available from Internet: http://www.nber.org/papers/w0303.pdf

Fisher, I. (2012). The Money Illusion. USA: Start Publishing LCCC. Original work published in 1928. [Accessed 20.12.2015]. Available from Internet: http://books.google.lt/books?hl=ru\&lr=\&id=ZWo-

AwAAQBAJ\&oi=fnd\&pg=PT3\&dq=Money+illusion\&ots=cgc7IaYrGr\&sig=L HeIbyIAahBkhu5vKQCWqzaG-

yY\&redir_esc=y\#v=onepage\&q=Money\%20illusion\&f=false

Gamble, A. (2007). The “Euro Illusion”: Illusion or Fact? Journal of Consumer Policy, (30), p. 323-336.

Gärling, T., \& Thøgersen, J. (2007). Effects of the Euro Changeover on Consumer Behaviour: Introduction to the Special Issue. Journal of Consumer Policy, (30), p. 303-311.

Gaston-Breton, C. (2006). The impact of the euro on the consumer decision process: theoretical explanation and empirical evidence. Journal of Product \& Brand Management, 15(4), p. 272-279.

Glauben, T., Loy, J.P., \& Meyer, J. (2004). Does money illusion matter? The impact of Euro on the vertical transmission of food price in Germany, Working paper, presented at the annual Meeting of the American Agricultural Economist Association (AAEA), Denver: AAEA. [Accessed 01.02.2016]. Available from Internet: http://ageconsearch.umn.edu/bitstream/20104/1/sp04lo01.pdf

Howitt, D. (2005). Introduction to SPSS in psychology. $3^{\text {rd }}$ edition. - Harlow: Pearson: Prentice Hall. 
Jonas, E. (2003). Introduction of the Euro - Goodbye to the Deutschmark, presented at the IAREP Euro-workshop, Vienna, July 3-5, 2003. [Accessed 15.01.2016]. Available from Internet: https://homepage.univie.ac.at/stephan.muehlbacher/euro/papers/Jonas-proc.pdf Kerem, K., Danneberg, T., Oper, J., \& Norden, A. (2013). Consumer attitudes and behavior related to the adoption of euro before the changeover. Baltic Journal of Management, 8(3), p. 269-285.

Miao, J., \& Xie, D. (2013). Economic Growth under Money Illusion. Journal of Economic Dynamics and Control, 37(1), p. 84-103.

Missier, F.D., Bonini, N., \& Ranyard, R. (2007). The Euro Illusion in Consumers' Price Estimation: An Italian-Irish Comparison in the Third Year of the Euro. Journal of Consumer Policy, (30), p. 337-354.

Raghubir, P., \& Srivastava, J. (2002). Effect of face value on product valuation in foreign currencies. Journal of Consumer Research, (29), p. 335-347.

Ramonienè, L., \& Brazys, D. (2007). Euro Introduction Effects on Individuals' Economic Decisions: Testing the Presence of Difference Assessment Account among Lithuanian and Latvian Consumers. Baltic Journal of Economics, 6(2), p. 29-55.

Shafir, E., Diamond, P., \& Tversky, A. (1997). Money Illusion. The Quarterly Journal of Economics, 112(2), p. 341-374.

Van Raaij, W.F., \& van Rijen, C.L.A. (2003). Money illusion and euro pricing, presented at the IAREP Euro-workshop, Vienna, July 3-5, 2003. Access on the Internet:

http://homepage.univie.ac.at/stephan.muehlbacher/euro/papers/vanRaaij\%26van Rijen.pdf

Wertenbroch, K., Soman, D., \& Chattopadhyay, A. (2007). On the Perceived Value of Money: The Reference Dependence of Currency Numerosity Effects. Journal of Consumer Research, 34(1), p. 1-10. 